\title{
Magnesium Replacement Does Not Improve Insulin Resis- tance in Patients With Metabolic Syndrome: A 12-Week Randomized Double-Blind Study
}

\author{
Maria de Lourdes Lima de Souza e Silva a, b, d, Thomaz Cruzc, Luiz Erlon Rodrigues ${ }^{\mathrm{a}}$, \\ Ana Marice Ladeia ${ }^{a}$, Olivia Bomfimª ${ }^{a}$ Lucas Olivieria, Juliana Melo ${ }^{a}$, \\ Raquel Correia ${ }^{a}$, Mirna Porto ${ }^{a}$, Alexandre Cedro ${ }^{a}$
}

\begin{abstract}
Background: To evaluate the effect of magnesium $(\mathrm{Mg})$ replacement on insulin resistance and cardiovascular risk factors in women with metabolic syndrome (MS) without diabetes.

Methods: This 12-week clinical randomized double-blind study compared the effects of $400 \mathrm{mg}$ /day of $\mathrm{Mg}$ with those of a placebo ( $\mathrm{n}=72$ ) on fasting glucose, insulin, HOMA-IR, lipid profile and CRP. $\mathrm{Mg}$ was measured in serum (SMg) and in mononuclear cells (MMg).
\end{abstract}

Results: Hypomagnesemia ( $\mathrm{SMg}<1.7 \mathrm{mg} / \mathrm{dL}$ ) was seen in $23.2 \%$ of patients and intracellular depletion in $36.1 \%$ of patients. The $\mathrm{MMg}$ means were lower in patients with obesity $(0.94 \pm 0.54 \mu \mathrm{g} /$ $\mathrm{mg}$ vs. $1.19 \pm 0.6 \mu \mathrm{g} / \mathrm{mg}, \mathrm{P}=0.04)$, and insulin resistance $(0.84 \pm$ $0.33 \mu \mathrm{g} / \mathrm{mg}$ vs. $1.14 \pm 0.69 \mu \mathrm{g} / \mathrm{mg}, \mathrm{P}<0.05) . \mathrm{Mg}$ replacement did not alter $\mathrm{SMg}(1.82 \pm 0.14 \mathrm{mg} / \mathrm{dL}$ vs. $1.81 \pm 0.16 \mathrm{mg} / \mathrm{dL}, \mathrm{P}=0.877)$ and tended to increment $\mathrm{MMg}(0.90 \pm 0.40 \mu \mathrm{g} / \mathrm{mg}$ vs. $1.21 \pm 0.73$ $\mu \mathrm{g} / \mathrm{mg}, \mathrm{P}=0.089)$. HOMA-IR did not alter in interventions nor in placebo group $(3.2 \pm 2.0$ to $2.8 \pm 1.9, \mathrm{P}=0.368 ; 3.6 \pm 1.9$ to $3.2 \pm$ 1.8 , respectively), neither did other metabolic parameters.

Conclusion: Serum and intracellular $\mathrm{Mg}$ depletion is common in patients with MS; however, $\mathrm{Mg}$ replacement in recommended dosage did not increase significantly $\mathrm{Mg}$ levels, neither reduced insulin resistance or metabolic control.

Keywords: Metabolic syndrome; Magnesium replacement; Magnesium and insulin resistance

\footnotetext{
Manuscript accepted for publication August 23, 2013

${ }^{a}$ Escola Bahiana de Medicina e Saude Publica, FBDC, Salvador, Bahia, Brasil

${ }^{\mathrm{b}}$ Universidade Salvador, UNIFACS, Salvador, Bahia, Brasil

${ }^{\mathrm{c}}$ Departmento de Medicina, Programa de Pos-graduacao em Medicina e Saude da Faculdade de Medicina da Bahia, Universidade Federal da Bahia, Brasil

${ }^{\mathrm{d}}$ Corresponding Author: Maria de Lourdes Lima, Rua Artur Gomes de Carvalho, 537/402-Pituba, Salvador, Bahia, Brasil.

Email: mlourdeslima@gmail.com
}

doi: http://dx.doi.org/10.14740/jocmr1580w

\section{Introduction}

An association between obesity, high fasting triglycerides, impaired glucose tolerance, hypertension and cardiovascular disease, has been recognized for a long time. These major risk factors tend to cluster together in many individuals, having insulin resistance as a main pathophysiological linkage [1], which was called metabolic syndrome (MS), a complex entity related to metabolic and cardiovascular risk factors and pro-thrombotic and pro-inflammatory states.

The whole comprehension of the insulin resistance pathogenesis is still in question. Magnesium $(\mathrm{Mg})$, a predominant intracellular ion, is a crucial metallic co-factor of many enzymatic reactions involved in post-receptor signaling and is critically involved in energy metabolism, fatty acid synthesis and glucose utilization [2]. Some authors suggest that $\mathrm{Mg}$ deficiency can contribute to insulin resistance [3], and epidemiological studies have described an inverse relationship between the intake levels of $\mathrm{Mg}$ rich foods and MS [4].

Hypomagnesemia has been seen in obese children $[5,6]$ and in people with MS [7]. Other studies demonstrate some benefits of $\mathrm{Mg}$ replacement in people with diabetes $[8,9]$, and those with insulin resistance [10].

The objective of this study was to evaluate the effect of $\mathrm{Mg}$ replacement on insulin resistance and on other cardiovascular risk factors in patients with MS without diabetes mellitus.

\section{Material and Methods}

A 12-week clinical randomized double-blind placebo-controlled trial, with 72 outpatients in an obesity reference center, was conducted.

The inclusion criteria for patients were they had to be between the ages of 21 and 70 years, with MS as defined by the International Diabetes Federation criteria that require the presence of abdominal obesity, defined by waist circumference $\geq 90 \mathrm{~cm}$ in men and $\geq 80 \mathrm{~cm}$ in women, for South American subjects, and two additional criteria, as follows: 


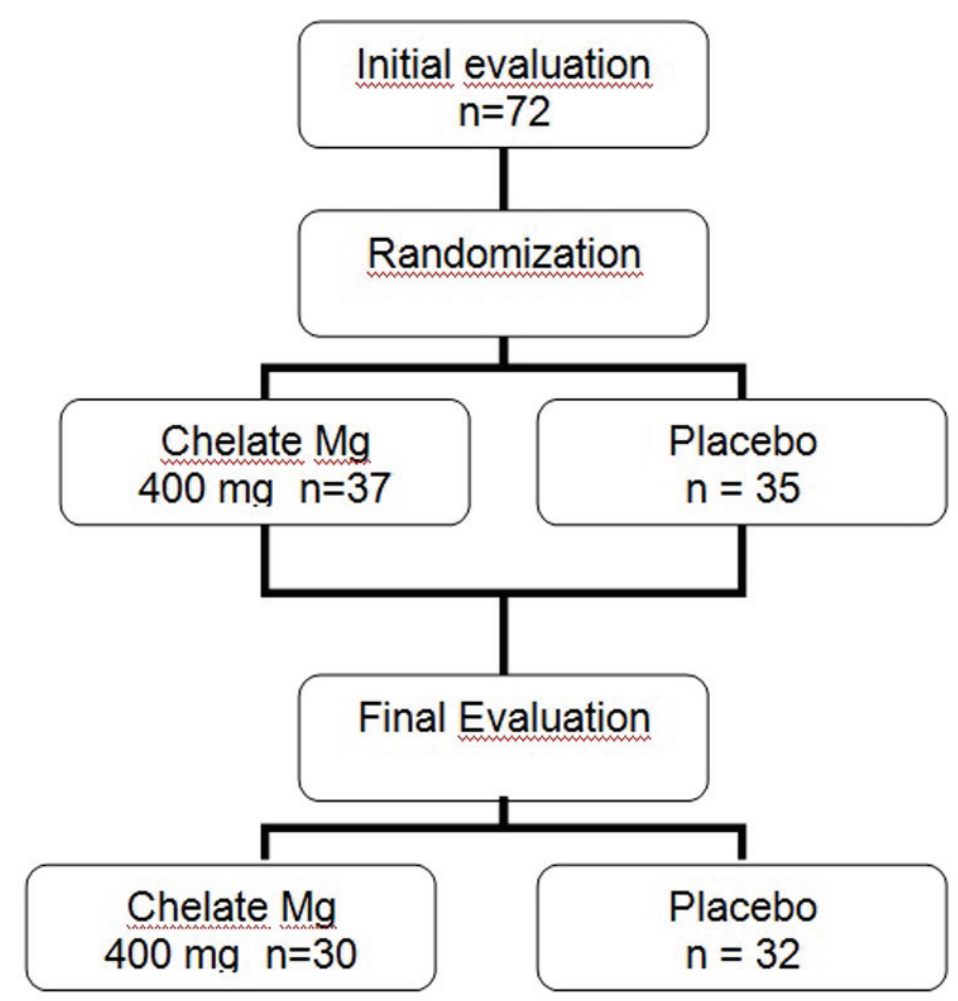

Figure 1. Study design.

1) hypertriglyceridemia $\geq 150 \mathrm{mg} / \mathrm{dL} ; 2$ ) HDL cholesterol < $50 \mathrm{mg} / \mathrm{dL}$ in women; 3 ) high blood pressure: $\geq 130 / \geq 85 \mathrm{~mm}$ $\mathrm{Hg}$; 4) fasting glucose $\geq 100 \mathrm{mg} / \mathrm{dL}$. Individuals on fibrates, on anti-hypertensive or anti-diabetic therapy were included in criteria 1, 3 and 4 respectively [11]. Patients with a high risk for hypomagnesaemia, such as those using diuretics, or those suffering from alcoholism or persistent diarrhea were excluded, as well those with a confirmed diagnosis of diabetes.

The primary trial end point was the change in HOMAIR index. Sample size was determinate by a statistical power of $80 \%$, alpha value 0.05 , and allowing non-improve in the HOMA-IR of 40 and $80 \%$ for the patients receiving $\mathrm{Mg}$ and placebo supplementation. The required sample size to detect a treatment effect was 26 patients in each group. Because of possible lost of follow-up, 35 patients were enrolled in each group.

\section{Clinical and laboratorial evaluation}

The patients were initially subjected to a clinical and laboratory evaluation and then randomized to receive placebo or $400 \mathrm{mg} /$ day of chelated $\mathrm{Mg}$ (divided in two daily doses for 12 weeks). All subjects received patronized nutritional recommendation and an exercise program for sessions at least three times a week, and they were instructed to not change the diet nor exercise program. Clinical evaluation was per- formed after 45 and 90 days after the baseline period. Laboratory assessment was done 90 days after $\mathrm{Mg}$ replacement. The study design is shown in Figure 1.

Compliance treatment was assessed by counting pills. All subjects gave their informed consent, and a local institutional ethics committee approved the study protocol.

The clinical evaluation included body mass index (BMI), calculated as body weight $(\mathrm{kg})$ divided by height $(\mathrm{m})$ squared; waist circumference, measured at the middle point between the iliac crest and the last costal arch, at minimal expiration, and in a supine position; blood pressure, measured twice. Achantosis nigricans and signs of inflammation were described if present.

All measurements and blood collection were performed in the morning following a $12-\mathrm{h}$ fast. The laboratory tests performed were fasting blood glucose, cholesterol, triglycerides, HDL cholesterol, uric acid, AST, ALT, $\gamma$ GT by dry chemistry (VITRUS 950 - 250), insulin by chemiluminescence's spectroscopy, high sensitivity C-reactive protein (CRP) by nephelometry, magnesium in serum (SMg) and in mononuclear cells (MMg) by atomic absorption spectrophotometry (VARIAN - 220).

The homeostasis model assessment (HOMA-IR) was used as a measure of insulin resistance (HOMA-IR $=$ insulin $(\mathrm{mU} / \mathrm{L}) \times$ glucose $(\mathrm{mmol} / \mathrm{L}) / 22.5)$ [12]. Insulin resistance was considered when HOMA-IR was higher than 2.7 [13]. Mononuclear cells separation was previously described [8]. 
Table 1. Baseline Characteristics of Mg and Placebo Groups

\begin{tabular}{|c|c|c|}
\hline & Placebo $(n=37)$ & Magnesium $(n=35)$ \\
\hline Age (years) & $46.6 \pm 12.3$ & $44.6 \pm 9.7$ \\
\hline BMI $\left(\mathrm{kg} / \mathrm{m}^{2}\right)$ & $35.1 \pm 6.3$ & $35.5 \pm 8.2$ \\
\hline Waist (cm) & $107.5 \pm 12.5$ & $<80$ \\
\hline Systolic blood pressure (mm Hg) & $134 \pm 17$ & $134 \pm 15$ \\
\hline Diastolic blood pressure $(\mathrm{mm} \mathrm{Hg})$ & $86 \pm 10$ & $85 \pm 8$ \\
\hline Glycemia (mg/dL) & $99 \pm 10$ & $103 \pm 15$ \\
\hline HOMA-IR & $3.31 \pm 1.86$ & $3.41 \pm 2.03$ \\
\hline Insulin (mU/L) & $13.4 \pm 6.4$ & $14.5 \pm 7.6$ \\
\hline Cholesterol (mg/dL) & $190 \pm 46$ & $203 \pm 46$ \\
\hline Triglycerides (mg/dL) & $137 \pm 61$ & $136 \pm 54$ \\
\hline HDL-c (mg/dL) & $43 \pm 10$ & $46 \pm 10$ \\
\hline LDL-c (mg/dL) & $120 \pm 39$ & $129 \pm 43$ \\
\hline GGT (mg/dL) & $44 \pm 51$ & $32 \pm 19$ \\
\hline PCR (mg/L) & $6.7 \pm 7.0$ & $5.8 \pm 5.3$ \\
\hline $\mathrm{SMg}(\mathrm{mg} / \mathrm{dL})$ & $1.80 \pm 0.22$ & $1.79 \pm 0.15$ \\
\hline $\operatorname{MMg}(\mu \mathrm{g} / \mathrm{mg})$ & $0.89 \pm 0.43$ & $0.90 \pm 0.40$ \\
\hline
\end{tabular}

At baseline, there were no differences for any parameters between groups.

The final suspension consisted of a mean of $97.5 \%$ lymphocytes, $2.3 \%$ monocytes and $0.15 \%$ neutrophils. MMg was expressed by cell proteins, which were measured using the Follin phenol reagent as described by Rodrigues et al [14].

\section{Statistical analysis}

Continuous quantitative data are expressed as means \pm standard deviation (SD). Two-tailed parametric tests were used for comparison of normally distributed variables, and nonparametric tests to compare variables when the assumption of normal distribution was not met. Student's paired t-tests or Wilcoxon tests were performed before and after treatment for comparison, and for non-paired comparison, independent t-tests or Mann-Whitney tests were used. Categorical variables were compared by Chi-squared or Fischer exact tests.
A two-tailed $\mathrm{P}$ value $\leq 0.05$ was considered statistically significant. Analysis was conducted with the intention to treat.

Data analysis was performed using the "Statistical Package for the Social Science" (SPSS, Inc., Chicago, IL, USA) 16.0 version.

\section{Results}

Seventy-two women with MS without diabetes were enrolled, aged $45.7 \pm 11.8$ years. Baseline characteristics were not statistically different between the groups (Table 1).

Hypomagnesemia was identified in $23.2 \%$ of patients and intracellular depletion in $36.1 \%$. Insulin resistance (HOMA-IR $\geq 2.7$ ) was observed in 36 patients $(50 \%)$. The MMg means were lower in patients with obesity $(0.94 \pm 0.54$ 


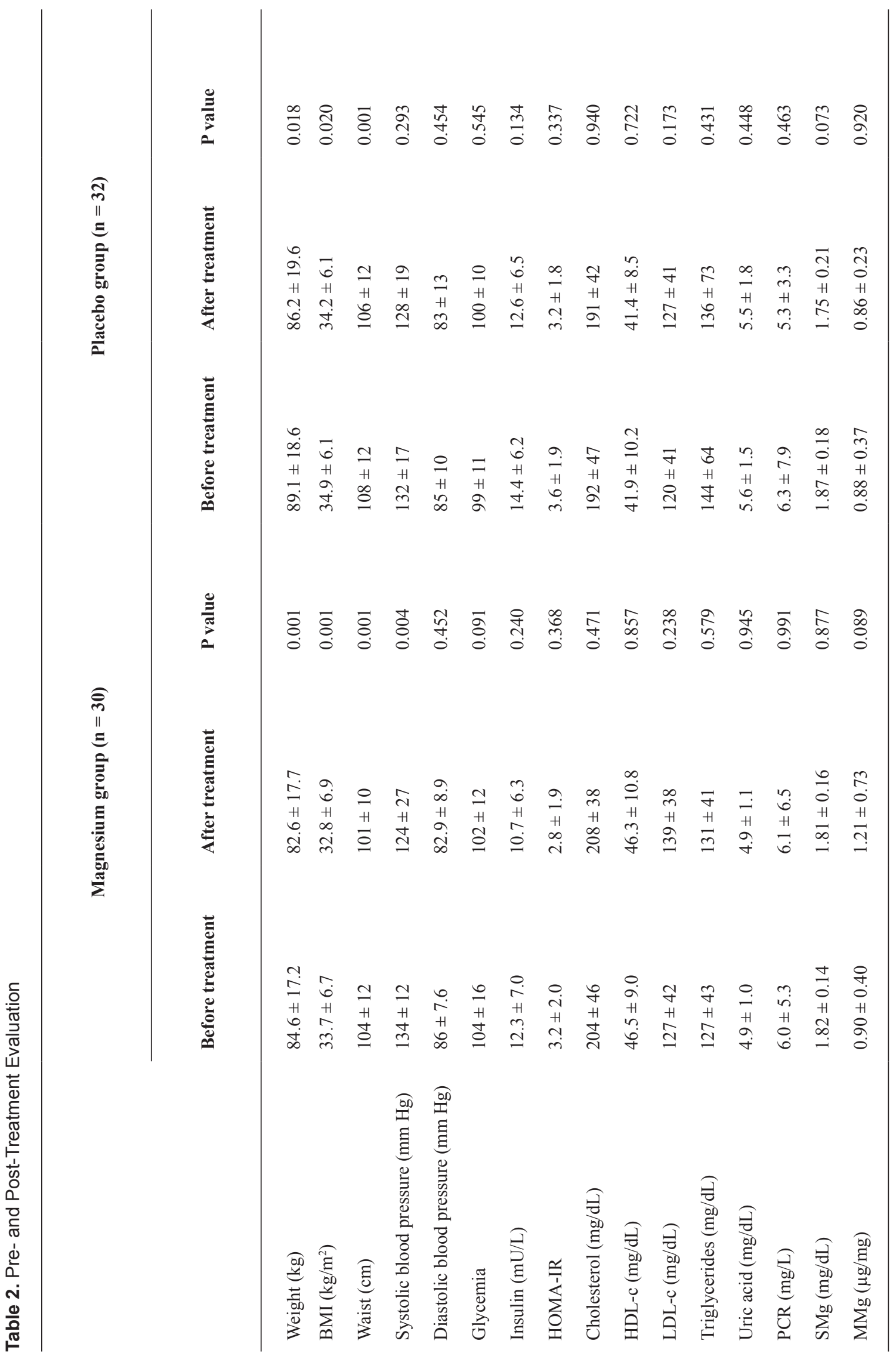


Table 3. Means Changes After Treatment

\begin{tabular}{llll}
\hline & Magnesium & Placebo & P \\
\hline$\Delta$ SBP (mm Hg) & $-8.5 \pm 27.8$ & $-4.0 \pm 19.7$ & 0.498 \\
$\Delta$ DBP (mm Hg) & $-2.0 \pm 9.3$ & $-1.9 \pm 13$ & 0.964 \\
$\Delta$ Fast blood glucose (mg/dL) & $-2.0 \pm 6.2$ & $+0.9 \pm 8.3$ & 0.129 \\
$\Delta$ Insulin & $-1.7 \pm 6.4$ & $-1.6 \pm 7.2$ & 0.938 \\
$\Delta$ HOMA-IR & $-0.36 \pm 2.10$ & $-0.32 \pm 1.80$ & 0.928 \\
$\Delta$ Triglycerides (mg/dL) & $+3.6 \pm 35$ & $-8.1 \pm 55.3$ & 0.337 \\
$\Delta$ HDL (mg/dL) & $-0.17 \pm 5.1$ & $-0.50 \pm 7.6$ & 0.847 \\
\hline
\end{tabular}

$\Delta$ : means change from baseline to end point between the beginning and the end of study; SBP: systolic blood pressure; DBP: diastolic blood pressure.

$\mu \mathrm{g} / \mathrm{mg}$ vs. $1.19 \pm 0.6 \mu \mathrm{g} / \mathrm{mg}, \mathrm{P}=0.04)$, and insulin resistance $(0.84 \pm 0.33 \mu \mathrm{g} / \mathrm{mg}$ vs. $1.14 \pm 0.69 \mu \mathrm{g} / \mathrm{mg}, \mathrm{P}<0.05)$.

Sixty-one patients completed treatment, and nine did not return to visits, or stopped treatment without an apparent reason. One patient was excluded in $\mathrm{Mg}$ group because of urticary issues.

The mean of weight loss in whole patients was $1.9 \pm 1.7$ $\mathrm{kg}$ (median, $1.7 \mathrm{~kg}$ ), with no significant difference between $\mathrm{Mg}$ and placebo group. They reduced waist circumference and BMI in the same proportions. Table 2 shows Mg concentrations and metabolic parameters before and after treatment.

Serum and intracellular $\mathrm{Mg}$ did not change in intervention nor in placebo group $(1.82 \pm 0.14 \mathrm{mg} / \mathrm{dL}$ to $1.81 \pm 0.16$ $\mathrm{mg} / \mathrm{dL}, \mathrm{P}=0.89$ and $0.90 \pm 0.40 \mu \mathrm{g} / \mathrm{mg}$ to $1.21 \pm 0.73 \mu \mathrm{g} /$ $\mathrm{mg}, \mathrm{P}=0.089)$. Systolic blood pressure reduced significantly only in the Mg group $(134 \pm 12 \mathrm{~mm} \mathrm{Hg}$ vs. $124 \pm 27 \mathrm{~mm}$ $\mathrm{Hg}, \mathrm{P}=0.004$ and $132 \pm 17 \mathrm{~mm} \mathrm{Hg}$ vs. $128 \pm 19 \mathrm{~mm} \mathrm{Hg}, \mathrm{P}$ $=0.293)$, and occurred in a tendency to reduction in glucose levels $(104 \pm 16 \mathrm{mg} / \mathrm{dL}$ to $102 \pm 12 \mathrm{mg} / \mathrm{dL}, \mathrm{P}=0.091 \mathrm{vs} .99$ $\pm 11 \mathrm{mg} / \mathrm{dL}$ and $100 \pm 10 \mathrm{mg} / \mathrm{dL}, \mathrm{P}=0.545)$. In spite of the blood pressure fall in $\mathrm{Mg}$ group, the compared means changes after treatment between the two groups did not shown significant difference (Table 3).

HOMA-IR did not reach statistically significant reduction in the both groups $(3.2 \pm 2.0$ to $2.8 \pm 1.9, \mathrm{P}=0.368$ in intervention group, and $3.6 \pm 1.9$ to $3.2 \pm 1.8$ in placebo group). The other variables did not alter with treatment.

The Mg supplement was well tolerated, and there were no relevant side effects, which occur in same proportion in patients taking $\mathrm{Mg}$ or placebo: slight epigastric pain $(5.4 \%$ vs. $8.6 \%)$, nausea $(2.7 \%$ vs. $5.7 \%)$, and diarrhea $(2.7 \%$ vs. $2.9 \%)$, which did not require treatment or interruption of medications.

\section{Discussion}

The present study showed a prevalence of hypomagnesemia in $23.2 \%$ of patients with MS without diabetes, and intramononuclear depletion in $36.1 \%$. This frequency of hypomagnesemia was higher when compared with healthy people $(3.6 \%)$ [8] and with hospitalized patients $(10 \%)$ [15], but lower than that found in by Guerrero Romero in patients with insulin resistance $(65.6 \%)$ [7].

There is no reported data about intracellular Mg depletion in patients with MS. In this study, the frequency of intramononuclear depletion was high, and more pronunciated in patients with obesity. Elsewhere, an independent association with BMI was shown. The low levels of intracellular $\mathrm{Mg}$ observed in patients with insulin resistance, present in 50\% of these patients, suggest a potential mechanism to explain this elevated prevalence of intracellular $\mathrm{Mg}$ depletion. Insulin has specific ionic effects to stimulate the transport of $\mathrm{Mg}$ from the extracellular to the intracellular compartment, with unclear mechanism [16].

Other postulated mechanism to explain the high prevalence of $\mathrm{Mg}$ depletion, could be the low ingestion of $\mathrm{Mg}$ rich foods by obese people, as described by others $[6,17]$. Unfortunately we did not measure the Mg intake accurately to test this hypothesis.

$\mathrm{Mg}$ replacement was well tolerated, with few side effects, comparable to the placebo group. However, after 3 months $400 \mathrm{mg} /$ day $\mathrm{Mg}$ supplementation, the serum and intracellular levels after did not increase significantly as was expected, a fact that may be explained by the insulin resistance present in the majority of the patients studied, impairing $\mathrm{Mg}$ entrance in the cells. The recommended dietary allowance for $\mathrm{Mg}$ for men and for women is 420 and 320 
$\mathrm{mg} /$ day respectively [18]. The tolerable upper daily intake for supplement in adults is $350 \mathrm{mg}$ according to $\mathrm{NIH}$, but the supplement dose in many studies varies from 200 to 630 $\mathrm{mg} /$ day $[10,19]$. Probably, in these patients with insulin resistance, higher doses of supplements may be necessary to correct intracellular $\mathrm{Mg}$ depletion.

Oral Mg supplements combine Mg with another substance as a salt (chloride, carbonate), oxide, or it can be chelated by amino acids. The amount of $\mathrm{Mg}$ in a compound and its bioavailability influences the effectiveness of the $\mathrm{Mg}$ supplement. $\mathrm{Mg}$ chloride or $\mathrm{Mg}$ lactate for example, has higher bioavailability than $\mathrm{Mg}$ oxide [20]. The best form for $\mathrm{Mg}$ replacements seems to be chelated $\mathrm{Mg}$, since it is not affected by the acidic $\mathrm{pH}$ of the stomach; fats and fibers do not interfere with its absorption, and the transport across the mucosa cell do not require vitamin intervention, as occurs with same metal ions absorption [21]. For these reasons, it was the form of replacement chosen in this study.

The importance of $\mathrm{Mg}$ on insulin sensitivity has been studied by many authors in diabetic patients [22, 23], and in non-diabetic patients [24]. Mg is essential for the phosphorilation of tyrosine kinase on the insulin receptor, as well as for other protein kinases involved in post-receptor insulin signaling [16]. For these reasons, Mg replacement may contribute to reducing insulin levels and fasting glucose levels.

In this study, however, after 12 weeks of taking chelated $\mathrm{Mg}$ (400 mg/day) or placebo, while following a hypo-caloric diet and an exercise program, patients lost weight and reduced their waist circumference in both groups, but HOMAIR did not show significant variation during the period of study. A fall in systolic blood pressure and a tendency to reduce glucose levels was seen only in the $\mathrm{Mg}$ group, but the mean changes comparison between groups at the end of treatment was not significantly different. On the other hand, Hadjistavri et al, using a high dosage of $\mathrm{Mg}$ pidolate (600 $\mathrm{mg}$ ), in hypertensive patient, showed a benefic effect in insulin resistance after 3 months supplementation [25].

The linkage between $\mathrm{Mg}$ deficiency and hypertension was first demonstrated in the Honolulu Heart Study [26], and was confirmed by prospective studies, including the cross-sectional study Atherosclerosis Risk in Communities (ARIC) study, which demonstrated a negative correlation of dietary and serum $\mathrm{Mg}$ levels with systolic and diastolic pressure [27]. Mg influences blood pressure regulation by modulating vascular tone and reactivity [28].

A limitation of this study deserves to be mentioned. We did not select patients with insulin resistance nor with $\mathrm{Mg}$ deficiency, a fact that can explain the difference in the results when compared with data of Guerrero-Romero who showed an improvement in insulin resistance in $\mathrm{Mg}$ deficient patients with insulin resistance, using $\mathrm{Mg}$ chloride, $2.5 \mathrm{~g}$ /day, what corresponds to $630 \mathrm{mg}$ of elementary $\mathrm{Mg}$, a higher dosage than the one used in this study, other difference that can explain the divergent results.
In conclusion, we demonstrate that a decrease in serum and in intracellular $\mathrm{Mg}$ concentration is common in patients with MS, especially in those with obesity and insulin resistance, but $\mathrm{Mg}$ replacement with $400 \mathrm{mg} /$ day of chelated $\mathrm{Mg}$ for 3 months did not correct $\mathrm{Mg}$ depletion neither improving insulin resistance nor metabolic control.

As insulin resistance can make $\mathrm{Mg}$ entrance into the cells difficult, more prolonged replacement in doses higher than usual are probably needed in order to establish if routine $\mathrm{Mg}$ replacement or selective administration in patients with MS, could improve metabolic control or prevent diabetes and cardiovascular diseases.

\section{Acknowledgement}

This project was supported by FAPESB (Fundacao de Amparo a Pesquisa do Estado da Bahia).

\section{References}

1. Reaven GM. Role of insulin resistance in human disease (syndrome X): an expanded definition. Annu Rev Med. 1993;44:121-131.

2. Barbagallo M, Dominguez LJ, Galioto A, Ferlisi A, Cani C, Malfa L, Pineo A, et al. Role of magnesium in insulin action, diabetes and cardio-metabolic syndrome X. Mol Aspects Med. 2003;24(1-3):39-52.

3. Ma B, Lawson AB, Liese AD, Bell RA, Mayer-Davis EJ. Dairy, magnesium, and calcium intake in relation to insulin sensitivity: approaches to modeling a dose-dependent association. Am J Epidemiol. 2006;164(5):449458.

4. He K, Liu K, Daviglus ML, Morris SJ, Loria CM, Van Horn L, Jacobs DR, Jr., et al. Magnesium intake and incidence of metabolic syndrome among young adults. Circulation. 2006;113(13):1675-1682.

5. Huerta MG, Roemmich JN, Kington ML, Bovbjerg VE, Weltman AL, Holmes VF, Patrie JT, et al. Magnesium deficiency is associated with insulin resistance in obese children. Diabetes Care. 2005;28(5):1175-1181.

6. Jose B, Jain V, Vikram NK, Agarwala A, Saini S. Serum magnesium in overweight children. Indian Pediatr. 2012;49(2):109-112.

7. Guerrero-Romero F, Rodriguez-Moran M. Low serum magnesium levels and metabolic syndrome. Acta Diabetol. 2002;39(4):209-213.

8. de Lordes Lima M, Cruz T, Pousada JC, Rodrigues LE, Barbosa K, Cangucu V. The effect of magnesium supplementation in increasing doses on the control of type 2 diabetes. Diabetes Care. 1998;21(5):682-686.

9. Rodriguez-Moran M, Guerrero-Romero F. Oral magnesium supplementation improves insulin sensitivity 
and metabolic control in type 2 diabetic subjects: a randomized double-blind controlled trial. Diabetes Care. 2003;26(4):1147-1152.

10. Guerrero-Romero F, Tamez-Perez HE, Gonzalez-Gonzalez G, Salinas-Martinez AM, Montes-Villarreal J, Trevino-Ortiz JH, Rodriguez-Moran M. Oral magnesium supplementation improves insulin sensitivity in nondiabetic subjects with insulin resistance. A double-blind placebo-controlled randomized trial. Diabetes Metab. 2004;30(3):253-258.

11. Alberti KG, Zimmet $\mathrm{P}$, Shaw J. The metabolic syndrome--a new worldwide definition. Lancet. 2005;366(9491):1059-1062.

12. Matthews DR, Hosker JP, Rudenski AS, Naylor BA, Treacher DF, Turner RC. Homeostasis model assessment: insulin resistance and beta-cell function from fasting plasma glucose and insulin concentrations in man. Diabetologia. 1985;28(7):412-419.

13. Geloneze B, Repetto EM, Geloneze SR, Tambascia MA, Ermetice MN. The threshold value for insulin resistance (HOMA-IR) in an admixtured population IR in the Brazilian Metabolic Syndrome Study. Diabetes Res Clin Pract. 2006;72(2):219-220.

14. Rodrigues LEA, Mathias CMC, Amorim MSP. Modificacao do metodo de Lowry para a quantificacao de proteinas. Rev Bras Patol Clin. 1989;25:1.

15. Rude RK, Singer FR. Magnesium deficiency and excess. Annu Rev Med. 1981;32:245-259.

16. Barbagallo M, Dominguez LJ. Magnesium metabolism in type 2 diabetes mellitus, metabolic syndrome and insulin resistance. Arch Biochem Biophys. 2007;458(1):4047.

17. Kurpad AV, Aeberli I. Low serum magnesium and obesity--causal role or diet biomarker? Indian Pediatr. 2012;49(2):100-101.

18. Institute of Medicine. Food and Nutrition Board. Dietary reference intakes: calcium, phosphorus, magnesium, vitamin D and fluoride. Washington DC: National
Academy Press. 1999.

19. Song Y, He K, Levitan EB, Manson JE, Liu S. Effects of oral magnesium supplementation on glycaemic control in Type 2 diabetes: a meta-analysis of randomized doubleblind controlled trials. Diabet Med. 2006;23(10):10501056.

20. Firoz M, Graber M. Bioavailability of US commercial magnesium preparations. Magnes Res. 2001;14(4):257262.

21. Ashmead HDW. Nutricao \& Minerais aminoacidos quelatos. 2a ed. Sao Paulo (Brasil): Attar Editorial. 1996.

22. Paolisso G, Ravussin E. Intracellular magnesium and insulin resistance: results in Pima Indians and Caucasians. J Clin Endocrinol Metab. 1995;80(4):1382-1385.

23. Lima ML, Pousada J, Barbosa C, Cruz T. Deficiencia de magnesio e resistencia a insulina em pacientes com diabetes mellitus tipo 2. Arq Bras Endocrinol Metabol. 2005;49:969-973.

24. Rosolova H, Mayer O, Jr., Reaven G. Effect of variations in plasma magnesium concentration on resistance to insulin-mediated glucose disposal in nondiabetic subjects. J Clin Endocrinol Metab. 1997;82(11):3783-3785.

25. Hadjistavri LS, Sarafidis PA, Georgianos PI, Tziolas IM, Aroditis CP, Hitoglou-Makedou A, Zebekakis PE, et al. Beneficial effects of oral magnesium supplementation on insulin sensitivity and serum lipid profile. Med Sci Monit. 2010;16(6):CR307-312.

26. Joffres MR, Reed DM, Yano K. Relationship of magnesium intake and other dietary factors to blood pressure: the Honolulu heart study. Am J Clin Nutr. 1987;45(2):469-475.

27. Kao WH, Folsom AR, Nieto FJ, Mo JP, Watson RL, Brancati FL. Serum and dietary magnesium and the risk for type 2 diabetes mellitus: the Atherosclerosis Risk in Communities Study. Arch Intern Med. 1999;159(18):2151-2159.

28. Sontia B, Touyz RM. Role of magnesium in hypertension. Arch Biochem Biophys. 2007;458(1):33-39. 